\title{
Efficient Energy Systems Models for Sustainable Food Processing
}

\author{
Azim Doğuş Tuncer ${ }^{1, a, *}$, Rukiye Mavuşş, ${ }^{2, b}$ Cemre Gökçe ${ }^{2, c}$, Meltem Koşan ${ }^{3, d}$, Mustafa Aktaş̧ \\ ${ }^{1}$ Energy Systems Engineering, Engineering-Architecture Faculty, Burdur Mehmet Akif Ersoy University, 15030 Burdur, Turkey \\ ${ }^{2}$ Gemak Food Processing Mach. and Trd. Inc., 06909 Ankara, Turkey \\ ${ }^{3}$ Energy Systems Engineering, Technology Faculty, Gazi University, 06560 Ankara, Turkey \\ * Corresponding author

\begin{tabular}{l|l}
\hline A R T I C L E I N F O & A B S T R A C T \\
Research Article & $\begin{array}{l}\text { The improvement and use of sustainable energy technologies are developing by the reason of } \\
\text { increasing energy demand. Due to the fossil fuels negative effects on the environment, energy } \\
\text { efficient building and their industrial applications have become an important research topic. To } \\
\text { increase energy efficiency in the food industry, the reduction of specific energy consumption is } \\
\text { needed. Food production facilities using energy for heating, cooling, drying, and specific processes } \\
\text { which requires high temperature. In this study, six energy system models have been suggested, and } \\
\text { presented for the use in food processing applications. These models are based on renewable energy, } \\
\text { waste heat management, solar energy, and efficient heat pump, ice storage heat pump, thermal } \\
\text { energy storage heat pump, drying with heat recovery and dehumidification. In addition to carbon } \\
\text { footprint reductant, the latest trend technologies are presented and the advantages are also discussed. } \\
\text { Especially hybrid systems that are combined with phase change materials and biomass are } \\
\text { investigated. }\end{array}$ \\
$\begin{array}{l}\text { Keywords: } \\
\text { Energy efficiency }\end{array}$ \\
$\begin{array}{l}\text { Food processing } \\
\text { Green buildings }\end{array}$
\end{tabular}

Hybrid renewable energy systems

Energy systems

\section{Introduction}

As the world population increases, energy consumption also increases, but the fossil fuels used in most of the world are decreasing and greenhouse gas emissions are increasing, too. Therefore, renewable energy sources have become much more significant because these sources will decrease the fossil fuel use to reduce environmental pollution and greenhouse gas emissions. Among all the industries, the food industry is one of the largest and the most energy-consuming industry in the world. Electricity and fossil fuels are the energy forms used in the food industry.

In food industry, labor, machinery and energy are substantially used to transform edible raw material to good quality products. Fuels like coal, natural gas petroleum, and electricity are used in food processing as basic energy types. In food industry, there are many different food processings and unit operations, and therefore, a different type of energy sources can be used (Wang, 2013). In heating processing including roasting, baking, cooking, frying and boiling, fuels and electricity are used, and in cooling processing including freezing, cooling and refrigeration, electricity is used almost in all (Drescher et al., 1997).

In order to achieve the EU's 20-20-20 goals, effective and efficient use of energy must be applied to the industry. This target consists $20 \%$ decrease in greenhouse emissions, $20 \%$ increment of renewable energy generation and $20 \%$ improvement in energy efficiency (European Comission, 2012). To achieve these goals in a short time will reduce the harmful gas emissions and carbon footprint, and this will prevent the global climate change. In Turkey, almost all the energy consumed in food industry is provided by fossil fuels.

Approximately $59 \%$ of the total energy in the food industry is used for heating processing and dehydration. Also, heating processing like pasteurization and 
sterilization, chilling and freezing, evaporation and drying consumes a lot of energy for food preservation. About $25 \%$ of the electricity in the whole food industry is used for cooling and refrigeration processing and $48 \%$ of the electricity is used for machine drive. In order to save energy in every unit operation, it is necessary to replace the high energy consuming units with the new ones, increase the energy efficiency and use renewable energy sources. While increasing energy efficiency in the food industry, the measures taken should be technically feasible, economical and practical (Wang, 2013).

Conventional drying processing is designed without energy efficiency. New systems are designed with the reuse of humid and recovery of heat energy with $40 \%$ of less energy consumption (Colak and Hepbasli, 2005). The percentage values of energy use in food industry in Turkey are shown in Fig. 1.

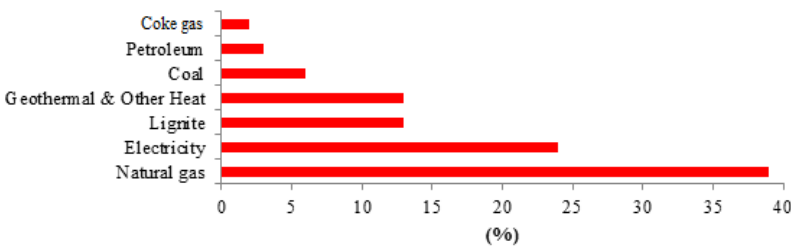

Figure 1 The percentage values of energy use in food industry in Turkey (General Directorate of Energy Affairs, 2016)

In pasteurization and sterilization, heating and cooling steps occur. During pasteurization, a heat pump can be used to combine energy flow between heating and cooling (Wang, 2008). 66\% of the primary energy can be saved by the heat pump system compared to conventional plate and double jacket milk pasteurization systems (Ozyurt et al., 2004). Low-temperature applications have $60 \%$ of the heat demand based on fossil fuel. A lot of examples exist in bakeries, meat processing, fish processing, distilleries and dairy industry notably using solar thermal and biomass for cooling/heating. Solar thermal heating systems have the potential in less energy-consuming industries, but since the initial capital is high and the distribution rates are low, it is necessary to reverse these conditions (IRENA, 2014).

The purposes of thermal energy storage (TES) systems are to store excess heat and reduce losses. These systems provide economic and environmental benefits by reducing fossil fuel consumption demands. Thermal energy produced by sources such as solar thermal energy, geothermal energy, fossil-fuel power plants, nuclear power plants, industrial waste heat, ice storage and biomass can be stored and used in different processes (Alva et al., 2018). Biogas can be used as fuel in the combined heat and power plants to meet the electricity and heat demands. The main components of biogas are $\mathrm{CH}_{4}$ and $\mathrm{CO}_{2}$, and their efficiency varies with different substrates, and the temperature is between $15^{\circ} \mathrm{C}$ and $65^{\circ} \mathrm{C}$ (Viklund and Lindkvist, 2015).

For solar PV (photovoltaic) systems, one of the major issues is currently only $15-20 \%$ of the solar radiation on a PV system could be converted to electrical energy, with the rest being transformed into waste heat, this part of waste could be reutilized as heat energy (Dincer and Aslan,
2008). In photovoltaic systems, the cooling processing is of great importance in order to increase efficiency and to create a secondary energy source (Karthick and Helen Catherine, 2014). PV/T (photovoltaic/thermal) technology was developed relying on PV system to enhance the overall efficiency of solar energy usage. A PV/T panel cannot only generate electricity but also collects thermal energy for hot water supply or space heating. For this purpose, photovoltaic-thermal systems could be used, which allow both electrical and thermal energy production. Previous studies about energy efficiency applications in the food industry are given in Table 1 .

As shown in Table 1, it is aimed to increase the use of waste heat and renewable energy technologies especially in food production in the industry. In this sense, 6 basic models are suggested as sustainable energy systems.

The development of efficient and economical energy storage is as important as the development of new energy sources. The time between supplying and using energy can be shortened by the storage of energy and this plays an important role in energy saving. PCMs can store or release energy during melting and solidification at certain temperatures, , and it supplies advantageous for the heat storage. When PCMs reach the temperature at which the phase change occurs, they absorb a large amount of energy by storing latent heat, but when the temperature goes down, they solidify (Gupta et al., 2013).

In the food industry, one of the oldest methods used for food production is drying. Solar drying processing does not require an energy source and expensive setup, so this makes it the cheapest method among all drying processing. In natural convection, the drying processing takes several days to complete because the air flow depends on the buoyancy-induced, but in forced convection, the air flow is supplied by a fan, operated by electricity/solar module or fossil fuel. Energy storage is necessary for continuous food drying because of variability and time-dependent characteristics of solar radiation (Amer et al., 2010).

The food supply chain is made up of several consecutive stages, each requiring energy for its various specific processes. Figure 2 illustrates final energy consumption in the food sector, from the point of global average and for high and low-gross domestic product (GDP) countries. Agriculture takes a similar role anyhow of GDP: $20 \%$ (low GDP) and $25 \%$ (high GDP). The share of energy utilized for retail, preparation and cooking is notably higher in low-GDP countries than in high-GDP countries. An advantageous pointer for the cost of energy of food products is the sum of all energy inputs along the production chain: the so-called embedded (or embodied) energy. Each processing step, including end-of-life management of the product and its residues, increases the amount of energy embedded in the product. Also it can be seen that processing, distribution, retail, preparation and cooking processes have remarkable amount of share in energy consumption.

The energy enclosed in food products does not account only for direct energy consumptions, such as heating an oven or operating a tractor, By contrast with, it includes also indirect energy uses, such as the energy needed to produce and transport manures or to operate irrigation systems (European Comission, 2015). 
Table 1 Previous studies about energy efficiency applications in food industry

\begin{tabular}{|c|c|c|c|}
\hline Applications - Method & Purpose & Conclusion & $\mathrm{R}$ \\
\hline Solar Dryer - PV/T & $\begin{array}{l}\text { A hybrid PVT greenhouse solar dryer in } \\
\text { mixed mode was designed for Institute } \\
\text { of Technology in India. It has been } \\
\text { developed for PVT greenhouse dryer } \\
\text { with parameters such as crop, } \\
\text { greenhouse and solar cell temperatures. }\end{array}$ & $\begin{array}{l}\text { The study resulted in increased product } \\
\text { quality and less loss of colour. }\end{array}$ & 1 \\
\hline $\begin{array}{l}\text { Food \& Drink Industry - } \\
\text { Heat Pump / Heat } \\
\text { Recovery }\end{array}$ & $\begin{array}{l}\text { The effect of heat pumps on heat } \\
\text { recovery and reduction of } \mathrm{CO}_{2} \\
\text { emissions in the French food \& } \\
\text { beverage industry has been investigated } \\
\text { in order to increase the need for energy } \\
\text { and reduce } \mathrm{CO}_{2} \text { emissions. }\end{array}$ & $\begin{array}{l}\text { The heat pump is a promising } \\
\text { technology that can be widely used in } \\
\text { the industrial sector because it can } \\
\text { operate with renewable energy and } \\
\text { emits a small amount of } \mathrm{CO}_{2} \text {. }\end{array}$ & 2 \\
\hline $\begin{array}{l}\text { Agri-Food Processes - } \\
\text { Energy Storage / Solar } \\
\text { Energy }\end{array}$ & $\begin{array}{l}\text { A study was carried out to meet the } \\
\text { energy requirements of a pasta factory } \\
\text { in Italy from solar collectors and a } \\
\text { concrete thermal energy storage system. }\end{array}$ & $\begin{array}{l}\text { The energy produced by the renewable } \\
\text { energy system corresponds to } 40 \% \text { of } \\
\text { the thermal energy requirement of the } \\
\text { pasta factory and the yield is around } \\
39 \% \text { per year. }\end{array}$ & 3 \\
\hline $\begin{array}{lcr}\text { Food Industry } & \text { Dryers } \\
\text { Heat Pump } & / & \text { Heat } \\
\text { Recovery } & \end{array}$ & $\begin{array}{l}\text { Heat recovery from air-to-air heat } \\
\text { exchangers and heat pump for dryers } \\
\text { used in the food industry was analysed. }\end{array}$ & $\begin{array}{l}\text { An air-to-air heat exchanger combined } \\
\text { with an HP can provide } 40 \% \text { of the } \\
\text { heating load and is } 20 \% \text { less costly. }\end{array}$ & 4 \\
\hline $\begin{array}{l}\text { Food Industry - Biomass + } \\
\text { Excess Heat }\end{array}$ & $\begin{array}{l}\text { In this study, the effect of internally } \\
\text { generated biogas integration of food } \\
\text { industry wastes produced by a food } \\
\text { company on greenhouse gas and } \\
\text { economy was investigated. }\end{array}$ & $\begin{array}{l}\text { In the industrial and agricultural sectors, } \\
\text { organic waste and fertilizer can be } \\
\text { digested together to produce biogas, this } \\
\text { reduces the fossil fuel use and increases } \\
\text { the positive impact on climate. }\end{array}$ & 5 \\
\hline $\begin{array}{l}\text { Food Industry - Energy } \\
\text { Savings }\end{array}$ & $\begin{array}{l}\text { A system has been designed to estimate } \\
\text { the energy consumption of the high- } \\
\text { energy food industry in the US, reduce } \\
\text { energy consumption and simulate the } \\
\text { state of the food industry. }\end{array}$ & $\begin{array}{l}\text { By } 2030 \text {, total food energy consumption } \\
\text { could be reduced by } 9.43 \% \text {. }\end{array}$ & 6 \\
\hline $\begin{array}{l}\text { Food Manufacturing - } \\
\text { Photovoltaic Solar System }\end{array}$ & $\begin{array}{l}\text { In this study, a feasibility study was } \\
\text { carried out for photovoltaic system used } \\
\text { to meet the energy demand in a food } \\
\text { production process. }\end{array}$ & $\begin{array}{l}\text { With a photovoltaic solar system of } \\
100 \mathrm{~kW} \text {, the plant's } \mathrm{CO}_{2} \text { productionhas } \\
\text { been significantly reduced and its } \\
\text { annual energy consumption has fallen } \\
\text { by } 39 \% \text {. }\end{array}$ & 7 \\
\hline $\begin{array}{l}\text { Fruit and Vegetable Drying } \\
- \text { Solar Dryer }+ \text { Thermal } \\
\text { Energy Storage }\end{array}$ & $\begin{array}{l}\text { In this conducted study, solar dryer } \\
\text { integrated with phase change material } \\
\text { was modelled to examine the drying } \\
\text { process and the product properties to be } \\
\text { dried. }\end{array}$ & $\begin{array}{l}\text { It has been found that the phase change } \\
\text { materials can be integrated into the solar } \\
\text { drying systems and the HS } 29 \text { can be } \\
\text { used as a phase change material (PCM) } \\
\text { for heat storage. }\end{array}$ & 8 \\
\hline $\begin{array}{l}\text { Drying Red Chilli - Solar } \\
\text { Assisted Heat Pump Dryer } \\
\text { + Biomass }\end{array}$ & $\begin{array}{l}\text { Biomass oven integrated heat pump } \\
\text { dryer was designed for drying red chilli } \\
\text { pepper and drying kinetics of red chilli } \\
\text { pepper was evaluated. }\end{array}$ & $\begin{array}{l}\text { The solar-assisted heat pump integrated } \\
\text { into the biomass furnace and sun-drying } \\
\text { was adapted to the mathematical models } \\
\text { and this dryer shortened the drying time } \\
\text { by } 82 \% \text {. }\end{array}$ & 9 \\
\hline $\begin{array}{l}\text { Drying Red Chilli - Solar } \\
\text { Assisted Biomass Dryer }+ \\
\text { Thermal Energy Storage }\end{array}$ & $\begin{array}{l}\text { In this study, a solar biomass hybrid air } \\
\text { heating system, which does not require } \\
\text { a conventional auxiliary heater, was } \\
\text { developed to meet the energy } \\
\text { requirement of the dryer used to dry red } \\
\text { chilli pepper. }\end{array}$ & $\begin{array}{l}\text { The results of the study show that the air } \\
\text { heating system provides a successful } \\
\text { drying in a continuous drying system, } \\
\text { offers an optimum quality product and } \\
\text { reduces the drying time by about } 66 \% \text {. }\end{array}$ & 10 \\
\hline $\begin{array}{l}\text { Drying Banana }- \text { Solar } \\
\text { Energy }+ \text { Heat Exchanger }\end{array}$ & $\begin{array}{l}\text { In this study, a hybrid solar dryer for } \\
\text { drying of banana was designed using } \\
\text { direct solar energy and a heat } \\
\text { exchanger. The dryer consists of a solar } \\
\text { collector, reflector, heat storage unit } \\
\text { with a heat exchanger and a drying } \\
\text { chamber. }\end{array}$ & $\begin{array}{l}\text { With the study, it has been observed that } \\
\text { the efficiency of the dryer can be } \\
\text { increased by returning } 65 \% \text { of the } \\
\text { drying air to the dryer, and the solar } \\
\text { energy can be collected in the best way } \\
\text { by adjusting the solar reflector and the } \\
\text { dryer to the angle of the sun. }\end{array}$ & 11 \\
\hline
\end{tabular}

R: References [1: Tiwari et al. (2016); 2: Seck et al. (2013); 3: Buscemi et al. (2018), 4: Wang et al. (2017); 5: Viklund and Lindkvist (2015); 6: Xu and Szmerekovsky (2017); 7: Mo (2016), 8: Gupta et al. (2013); 9: Yahya (2016); 10: Leon and Kumar (2015); 11: Amer et al. (2010) 


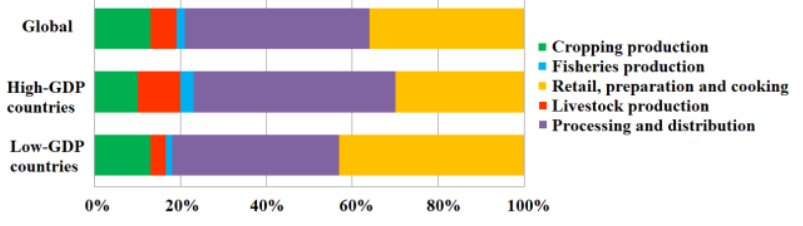

Figure 2 Final energy consumption in the food sector (European Comission, 2015)

In order to meet more natural energy sources, in the food industry, which is one of the most energy consuming industries, energy models for more environmentally friendly were proposed. These energy models mentioned in this article will be able to reduce fossil fuel-electricity consumption, recover heat wastes-losses and process wastes and use renewable energy sources to produce electricity.

\section{Energy Efficiency Equations for Energy Systems Models}

Thermodynamic equations determine the performance of the energy systems. Related abbreviations are given in Table 3. The first law of thermodynamics states that energy cannot be created or destroyed, but it can be converted from one form to another and can be briefly defined with the following equation:

$$
\dot{\mathrm{E}}_{\text {in }}-\dot{\mathrm{E}}_{\text {out }}=\Delta \dot{\mathrm{E}}_{\text {system }}
$$

$\dot{\mathrm{E}}_{\mathrm{in}} \quad$ : Total energy inlet the system $(\mathrm{kW})$

$\dot{\mathrm{E}}_{\text {out }}$ : Total energy outlet the system $(\mathrm{kW})$

The first law thermal efficiency is expressed as:

$$
\eta_{\text {th }}=\frac{\text { Net work output }}{\text { Total heat input }}=\frac{\dot{\mathrm{W}}_{\text {net,out }}}{\dot{\mathrm{Q}}_{\text {in }}}
$$

$\eta_{\text {th }}:$ Thermal efficiency (the first law efficiency), (\%)

The second law of thermodynamics reveals that the quality of energy should be taken into consideration as well as the quantity, and this indicates that changes in nature occur in the direction of reducing the quality of energy. The second law efficiency is the ratio of the thermal efficiency to the highest (reversible) efficiency that can occur under the same conditions (Çengel and Boles, 215):

$$
\eta_{\mathrm{II}}=\frac{\eta_{\text {th }}}{\eta_{\mathrm{th}, \mathrm{tr}}}
$$

The energy equations used in the proposed energy models for the food sector are summarized below:

PV unit efficiency can be calculated by the following equation:

$$
\eta_{P V}=\frac{P_{e}}{I A_{c}}=\frac{I_{P V} U_{P V}}{I A_{c}}
$$

$\mathrm{P}_{\mathrm{e}} \quad$ : Electrical power, $(\mathrm{kW})$

$\mathrm{I}_{\mathrm{PV}}$ : PV current, (Amper)

$\mathrm{U}_{\mathrm{PV}}: \mathrm{PV}$ voltage, (Volt)

I : Solar irradiance, $\left(\mathrm{W} / \mathrm{m}^{2}\right)$

$A_{c}$ : Collector area, $\left(\mathrm{m}^{2}\right)$
Thermal efficiency of PV/T panel can be expressed as below:

$$
\eta_{\mathrm{th}}=\frac{\dot{\mathrm{Q}}_{\mathrm{th}}}{\mathrm{IA}_{\mathrm{c}}}=\frac{\dot{\mathrm{mc}}_{\mathrm{p}}\left(\mathrm{T}_{\mathrm{o}}-\mathrm{T}_{\mathrm{i}}\right)}{\mathrm{IA}_{\mathrm{c}}}
$$

$\dot{\mathrm{m}}$ : Mass flow rate, $(\mathrm{kg} / \mathrm{s})$

$\mathrm{c}_{\mathrm{p}}$ : Specific heat, $(\mathrm{kJ} / \mathrm{kg} \mathrm{K})$

$\mathrm{T}_{\mathrm{o}}$ : Outlet fluid temperature of the collector, $\left({ }^{\circ} \mathrm{C}\right)$

$\mathrm{T}_{\mathrm{i}} \quad$ : Inlet fluid temperature of the collector, $\left({ }^{\circ} \mathrm{C}\right)$

$\mathrm{PV} / \mathrm{T}$ collector efficiency value can be calculated the following equation:

$$
\begin{aligned}
& \eta_{\mathrm{PV}, \mathrm{T}}=\eta_{\mathrm{PV}}+\eta_{\mathrm{th}}=\frac{\mathrm{P}_{\mathrm{e}}+\dot{\mathrm{Q}}_{\mathrm{th}}}{\mathrm{IA}_{\mathrm{c}}} \\
& \dot{\mathrm{Q}}_{\mathrm{th}}: \text { Thermal power, }(\mathrm{kW})
\end{aligned}
$$

Latent heat energy storage can be computed by the following equation:

$\dot{\mathrm{Q}}_{\mathrm{s}}=\dot{\mathrm{mL}}$

$\dot{\mathrm{Q}}_{\mathrm{s}} \quad$ : Stored power, $(\mathrm{kW})$

$\mathrm{L} \quad$ : Latent heat, $(\mathrm{kJ} / \mathrm{kg})$

The energy storage capacity of phase change material (both paraffin or ice etc.) is given according to the state of the liquid fraction $(\varnothing) 3$ as follows (Kosan and Aktas, 2018):

$\mathrm{Q}=\left\{\begin{array}{cr}\text { if } \emptyset=0, & \mathrm{Q}=\mathrm{m}_{\mathrm{bf}} \mathrm{c}_{\mathrm{p}, \mathrm{bf}} \Delta \mathrm{T}_{\mathrm{bf}}+\mathrm{m}_{\mathrm{pcm}} \mathrm{c}_{\mathrm{p}, \mathrm{f}} \Delta \mathrm{T}_{\mathrm{pcm}} \\ \text { if } 0<\emptyset<1, & \mathrm{Q}=\mathrm{m}_{\mathrm{bf}} \mathrm{c}_{\mathrm{p}, \mathrm{bf}} \Delta \mathrm{T}_{\mathrm{bf}}+\mathrm{m}_{\mathrm{pcm}} \mathrm{L} \\ \text { if } \emptyset=1, & \mathrm{Q}=\mathrm{m}_{\mathrm{bf}} \mathrm{c}_{\mathrm{p}, \mathrm{bf}} \Delta \mathrm{T}_{\mathrm{bf}}+\mathrm{m}_{\mathrm{pcm}} \mathrm{c}_{\mathrm{p}, \mathrm{s}} \Delta \mathrm{T}_{\mathrm{pcm}}\end{array}\right\}$

$\mathrm{m}_{\mathrm{bf}} \quad$ : Mass of base fluid $(\mathrm{kg})$

$\mathrm{m}_{\mathrm{pcm}}$ : Mass of phase change fluid $(\mathrm{kg})$

$c_{\mathrm{p}, \mathrm{bf}} \quad$ : Specific heat of base fluid $(\mathrm{kJ} / \mathrm{kg} \mathrm{K})$

$c_{p, f} \quad:$ Specific heat of phase change fluid $(\mathrm{kJ} / \mathrm{kg} \mathrm{K})$

$c_{p, s} \quad$ : Specific heat of phase changing material in solid phase $(\mathrm{kJ} / \mathrm{kg} \mathrm{K})$

$\Delta \mathrm{T}_{\mathrm{bf}} \quad$ : Temperature difference of base fluid (K)

$\Delta \mathrm{T}_{\mathrm{pcm}}$ : Temperature difference of phase change fluid $(\mathrm{K})$

The maximum power coefficient of wind energy can be explained as:

$\mathrm{P}_{\mathrm{o}}=1 / 2 \rho \mathrm{AV}_{\mathrm{i}}^{3} \mathrm{C}_{\mathrm{p}}$

$\mathrm{P}_{\mathrm{o}} \quad$ : Maximum power coefficient of wind energy, $(\mathrm{kW})$

$\mathrm{V}_{\mathrm{i}}$ : Velocity inlet of wind turbine, $(\mathrm{m} / \mathrm{s})$

$\rho \quad$ : Density of air, $\left(\mathrm{kg} / \mathrm{m}^{3}\right)$

Where $\mathrm{C}_{\mathrm{p}}$ is referred to as the Betz Law. The Betz Law, in theory, implies that a wind turbine efficiency will be a maximum of $59 \%$ (Kokey, 2013). 
The coefficient of heating performance of the heat pump COP can be calculated with the equation given below:

$$
\mathrm{COP}=\frac{\dot{\mathrm{Q}}_{\text {cond }}}{\dot{\mathrm{W}}_{\text {comp }}}
$$

$\dot{\mathrm{Q}}_{\text {cond }}$ : Condenser power, $(\mathrm{kW})$

$\dot{\mathrm{W}}_{\text {comp }}$ : Compressor power, $(\mathrm{kW})$

Biomass boiler efficiency can be expressed as below:

$$
\eta=\frac{Q_{0}}{H_{a} \eta_{c}}
$$

$\mathrm{Q}_{\mathrm{o}} \quad$ : Obtained energy, $(\mathrm{kJ})$

$\mathrm{H}_{\mathrm{a}}$ : Lower calorific value of fuel, $\left(\mathrm{kJ} / \mathrm{m}^{3}\right)$

$\eta_{\mathrm{c}}$ : Combustion efficiency, $(\%)$

The temperature ratio of a heat recovery unit for exhaust air can be calculated using the following equation:

$$
\eta_{\mathrm{e}}=\frac{\mathrm{T}_{\mathrm{ex}}-\mathrm{T}_{\mathrm{EHR}}}{\mathrm{T}_{\mathrm{ex}}-\mathrm{T}_{\mathrm{outd}}}
$$

$\eta_{\mathrm{e}} \quad$ : Heat recovery unit efficiency, $(\%)$

$\mathrm{T}_{\text {ex }}$ : Exhaust air temperature before a heat recovery unit $\left({ }^{\circ} \mathrm{C}\right)$

$\mathrm{T}_{\mathrm{EHR}}$ : Exhaust air temperature after a heat recovery unit $\left({ }^{\circ} \mathrm{C}\right)$

$\mathrm{T}_{\text {outd }}$ : Outdoor air temperature $\left({ }^{\circ} \mathrm{C}\right)$

The thermal dryer efficiency is the ratio of energy used to evaporate water in the product $\left(\dot{\mathrm{E}}_{\mathrm{u}}\right)$ to the energy provided to the air during drying $\left(\dot{\mathrm{E}}_{\mathrm{F}}\right)$ and defined as in the following form (Balbine et al., 2015):

$$
\eta_{d}=\frac{\dot{E}_{u}}{\dot{\mathrm{E}}_{\mathrm{F}}}
$$

$\eta_{d} \quad$ :Thermal dryer efficiency, (\%)

\section{Suggested Models}

In the food industry, especially for dairy production, some processes such as washing, evaporation, drying, pasteurization, sterilization, cooling, freezing, and fermentation are commonly applied. These processes are described below as:

- Washing: Washing with alkali to dissolve milk and fat proteins $\left(30\right.$ minutes at $\left.75-80^{\circ} \mathrm{C}\right)$. Washing with acid to dissolve galactites $\left(30\right.$ minutes at $\left.60-65^{\circ} \mathrm{C}\right)$.

- Evaporation: It is used to remove the water in the product at the desired rate and to obtain a concentrated product $\left(55-60^{\circ} \mathrm{C}\right)$.

- Drying: It is applied to reduce the moisture content of the product to $5 \%$ or less $\left(180-220^{\circ} \mathrm{C}\right)$.

- Pasteurization: It is applied for the destruction of all microorganisms that cause disease (15-20 seconds at $\left.72-75^{\circ} \mathrm{C}\right)$.

- Sterilization: It is the process of killing all bacteria including spores in the product (2-4 seconds at 132$\left.135^{\circ} \mathrm{C}\right)$.
- Cooling: It is the process of the product in order to stop the progress of acidity in the product (at $4-10^{\circ} \mathrm{C}$ ).

- Freezing: It is the process of preparing the milk and mixture materials to be added to the milk and passing it through various processes and freezing (at $-18^{\circ} \mathrm{C}$ ).

- Fermantation: It is the phenomenon of inoculating various bacteria into the raw material of the product to be obtained and breaking down the large molecular components into small molecular components (3-6 hours at $42-45^{\circ} \mathrm{C}$ ) (Bylung, 2003).

The heat required for these processes (generally operation temperature is below $200^{\circ} \mathrm{C}$ ) is met by the steam or hot water systems which are produced from fossil fuels. Electrical energy is necessary for compressors, pumps, grinders, and various devices. The usage of hybrid systems that can produce both heat and electricity, that can benefit from waste heat, and that store the energy is very important in terms of energy efficiency and sustainability. For this purpose, six different models have been developed to ensure sustainable energy systems, especially for the food processing.

\section{Model 1}

In this model, the electricity and heat load that is required for the food processing are met from renewable energy such as solar, wind and biomass. The basic principle of the proposed Model 1 for the food process is shown in Figure 3. Electricity energy will be generated from PV units and wind turbines on the other hand, heat energy will be produced from biomass. PV units, which are the semiconductor material, generate directly electricity under solar irradiation. The efficiency of the PV units can be calculated as given in Eq. 4. The electrical energy generated by the wind turbine and PV will be stored in the batteries and it will feed the system. The maximum power coefficient of wind energy is clarified in Eq. 9. The heat energy required for the food processing will be produced from the biomass energy, which is a popular renewable energy resource by obtaining the heat energy via burning the plant waste. The expression of efficiency of the biomass boiler is shown in Eq. 11 .

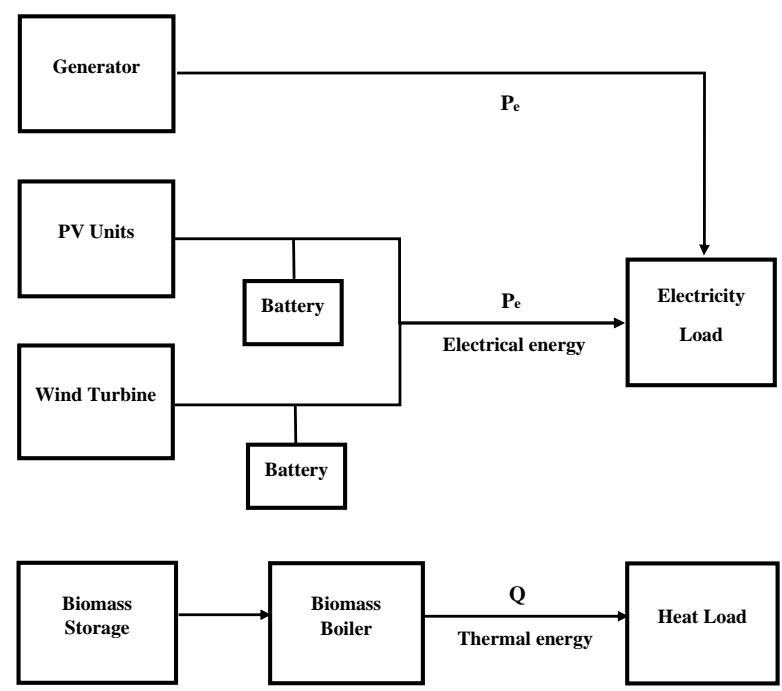

Figure 3 Renewable energy model for food processing 
Model 2

In this model, waste heat in the food industry will be utilized for heating and cooling load and thermal energy storage. The basic principle of the proposed Model 2 for the food processing is shown in Figure 4. Waste heat will be used directly as heat load for heating and cooling in food processing. If the waste heat is not enough for the heat load, the auxiliary heater will be activated and it will feed the system. Heat recovery unit efficiency is calculated according to the given in Eq. 12. The cooling processing required for the food processing will be carried out with the absorption chiller, which receives the heat from the waste heat. Thermal energy storage will be carried out with latent heat energy storage, which has high storage capacity. Latent heat storage material which most commonly uses paraffin will be selected according to the temperature of the waste heat source (Kosan and Aktas, 2018). Thermal energy will be stored and in case of inadequate heat load, it will support the heating system for a while. A part of the waste heat will be evaluated in the energy storage tank, and a part of will be used for heating and cooling. The energy storage capacity of latent latent heat material is obtained by the equation given in Eq. 8 .

\section{Model 3}

In this model, the electricity, heat and cooling load that is required for the food processing are met from the solar energy and heat pump system. The basic principle of the proposed Model 3 for the food processing is shown in Figure 5. Both electricity and heat load will be supplied by $\mathrm{PV} / \mathrm{T}$, which can simultaneously produce heat and electricity energy from solar energy. Furthermore, the heat pump, which can efficiently operate even at the low temperature, will support the heat and cooling load. Heat pump system feeds heat load by producing ice to meet the cooling requirement. Thus, both heating and cooling will simultaneously be done for food processing. The electrical energy required for the operation of the heat pump can be met by the electricity generated from PV/T. The efficiency of the PV/T collector is the sum of PV unit efficiency and thermal efficiency as shown in Eq. 6. Furthermore, the COP of the heat pump is calculated according to the equation given in Eq. 10.

\section{Model 4}

In this model, cooling load that is required for the food processing is met from heat pump system by using the ice storage tank. The basic principle of the proposed Model 4 for the food processing is shown in Figure 6. During offpeak hours of energy such as night, the energy is stored in the ice, and during peak hours of energy, the stored energy will be used for the cooling processing in the food processing. In this way, this system will significantly save the cost of energy for cooling processing.

\section{Model 5}

In this model, the heat load that is required for the food processing is met from the heat pump system with thermal energy storage. The basic principle of the proposed Model 5 for the food processing is shown in Figure 7. The energy obtained from the condenser of the heat pump will be stored by using the phase change material in the thermal storage tank. During the peak of heat energy, the energy in the thermal storage tank will support the heat load. The thermal efficiency of solar collector can be computed as shown in Eq. 5.

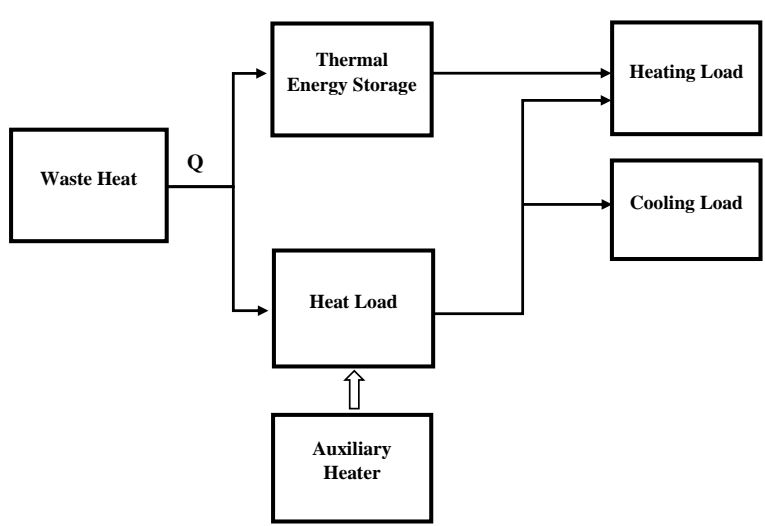

Figure 4 Waste heat management model for food processing

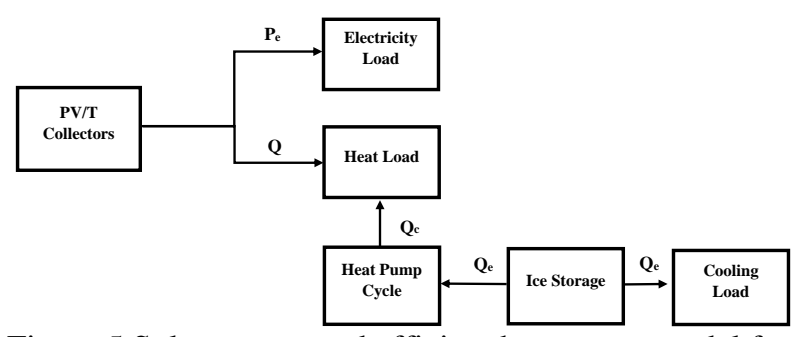

Figure 5 Solar energy and efficient heat pump model for food process

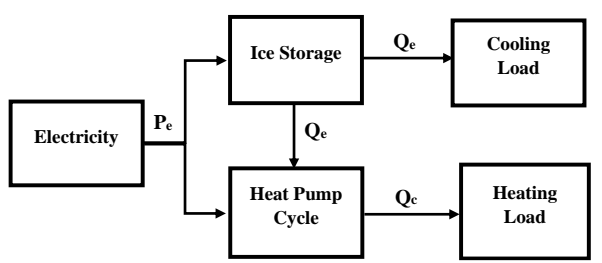

Figure 6 Ice storage heat pump model for food process

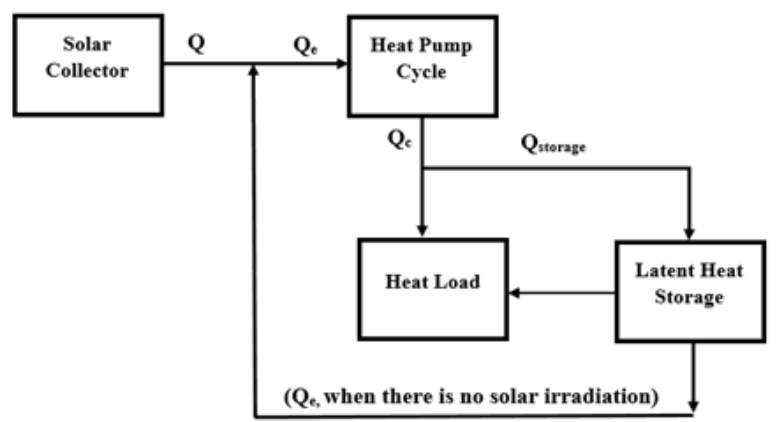

Figure 7 Thermal energy storage heat pump model for food processing

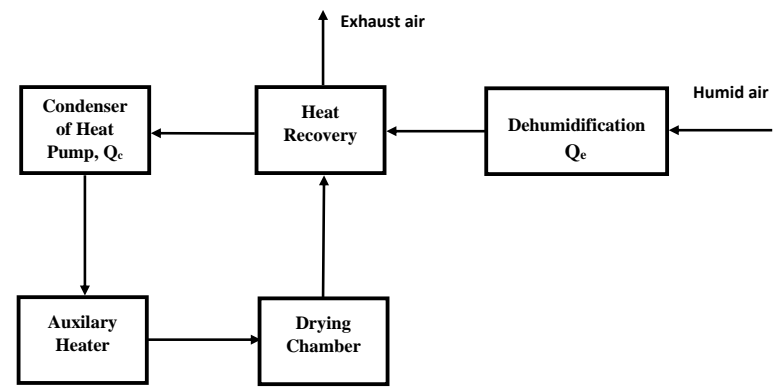

Figure 8 Drying system with the heat recovery and dehumidification model for food processing 


\section{Model 6}

In this model, drying air that is required the food processing is met from the heat recovery system and the heat pump. The basic principle of the proposed Model 6 for the food processing is shown in Figure 8. Drying system with the dehumidification and heat recovery are designed for dry and hot air which are needed in the food processing. In this system, the moisture of the humid air is firstly removed and then preheated at the heat recovery. The preheated dry air is reheated in the condenser. If the heated dry air is not at the desired air temperature, it can be heated with the auxiliary heater. In this way, the desired conditions for the drying chamber are provided and the waste heat in the drying chamber is transferred to drying air by using heat recovery. Efficiency of dryer can be calculated as shown in Eq.13.

In Table 2, the energy loads are summarized for the models. According to the properties and temperature given in the table, in the suggested models, the desired conditions in food processing can be provided directly or with auxiliary system. The proposed models and combinations of these can be applied accordance with the conditions of processing at the food factory.

Table 2 Comparison of different models

\begin{tabular}{|c|c|c|c|c|c|c|}
\hline Specifications & Model 1 & Model 2 & Model 3 & Model 4 & Model 5 & Model 6 \\
\hline Electricity Load & $\checkmark$ & - & $\checkmark$ & - & - & - \\
\hline Heat Load & $\checkmark$ & $\checkmark$ & $\checkmark$ & $\checkmark$ & $\checkmark$ & $\checkmark$ \\
\hline Cooling Load & - & $\checkmark$ & $\checkmark$ & $\checkmark$ & - & $\checkmark$ \\
\hline Energy storage & $\checkmark$ & $\checkmark$ & $\checkmark$ & $\checkmark$ & $\checkmark$ & - \\
\hline $\begin{array}{l}\text { Main } \\
\text { application } \\
\text { principle }\end{array}$ & $\begin{array}{l}\text { Renewable } \\
\text { energy wind, } \\
\text { solar and } \\
\text { biomass }\end{array}$ & $\begin{array}{c}\text { Cooling and } \\
\text { heating } \\
\text { using waste } \\
\text { heat source }\end{array}$ & $\begin{array}{l}\text { Electricity } \\
\text { and heat } \\
\text { generation } \\
\text { with PV-T } \\
\text { solar } \\
\text { collectors }\end{array}$ & $\begin{array}{l}\text { Energy } \\
\text { storage for } \\
\text { cooling } \\
\text { systems }\end{array}$ & $\begin{array}{c}\text { Solar } \\
\text { assisted heat } \\
\text { pump system } \\
\text { with heat } \\
\text { storage for } \\
\text { heating } \\
\end{array}$ & $\begin{array}{c}\text { Heat pump } \\
\text { drying with } \\
\text { dehumidification } \\
\text { and heat recovery }\end{array}$ \\
\hline $\begin{array}{l}\text { Application } \\
\text { properties } \\
\text { depends on } \\
\text { desired } \\
\text { temperature }\end{array}$ & $\begin{array}{l}\text { Biomass boiler } \\
\text { can be designed } \\
\text { for necessary } \\
\text { temperature, the } \\
\text { continuity of } \\
\text { electricity } \\
\text { production is } \\
\text { provided with } \\
\text { generator }\end{array}$ & $\begin{array}{l}\text { Reachable } \\
\text { temperature } \\
\text { depends on } \\
\text { temperature } \\
\text { of waste } \\
\text { fluid, } \\
\text { suggested } \\
\text { model has } \\
\text { auxiliary } \\
\text { heater. }\end{array}$ & $\begin{array}{c}\text { Electricity } \\
\text { generation } \\
\text { with solar } \\
\text { energy, this } \\
\text { suggested } \\
\text { model can } \\
\text { be used at } \\
-10^{\circ} \mathrm{C} \\
\text { (cooling), } \\
\text { to product } \\
\text { ice ball, } \\
+50^{\circ} \mathrm{C} \\
\text { (heating) } \\
\end{array}$ & $\begin{array}{c}\text { If both } \\
\text { cooling and } \\
\text { heating are } \\
\text { necessary, } \\
\text { this } \\
\text { suggested } \\
\text { model can } \\
\text { be used at } \\
-10^{\circ} \mathrm{C} \\
(\text { cooling), } \\
+50^{\circ} \mathrm{C} \\
\text { (heating) }\end{array}$ & $\begin{array}{c}\text { Reachable } \\
\text { heated fluid } \\
\text { temperature } \\
\text { is } \\
+55^{\circ} \mathrm{C} \text { at } \\
\text { winter } \\
\text { conditions, } \\
\text { with the } \\
\text { modification } \\
\text { of energy } \\
\text { storage. }\end{array}$ & $\begin{array}{c}\text { Relative } \\
\text { humidity of } \\
\text { drying air can be } \\
\text { controlled, and } \\
\text { max. reachable } \\
\text { air temperature is } \\
+55^{\circ} \mathrm{C}\end{array}$ \\
\hline
\end{tabular}

These models must be analysed for food processing systems under the thermal-electrical boundary conditions. According to the design parameters, Model 1 is suitable to use the energy effectively for evaporators, pasteurizers and heat exchangers. Model 2 and Model 3 are applicable for walled cooking boilers; pasteurizers and jacketed boilers, respectively. Also, Model 4 can be used for heat exchangers and Model 5 is applicable for both heat exchangers and evaporators. Model 6 is suitable for designing drying applications for the food processing.

\section{Conclusion}

In industry, energy consumption is increasing because of the growing population and increasing demands. Food factory designers have to take the suggested sustainable energy systems into consideration. Therefore, six efficient energy system models have been suggested for food processing designers. When renewable energy assisted hybrid systems and waste heat recovery applications are used, specific energy consumption values of food processing significantly decrease. These models are important to decrease environmental pollution. Thy will have contributions into the energy efficiency applications in the food industry. In this way, fossil fuels consumption in the food industry will be substantially reduced by the suggested energy models and the usage of more efficient energy system devices will become widespread in the food industry.

\section{References}

Alva G, Lin Y, Fang G. 2018. An overview of thermal energy storage systems. Energy. 144: 341-378.

Amer BMA, Hossain MA, Gottschalk K. 2010. Design and performance evaluation of a new hybrid solar dryer for banana. Energy Conversion and Management. 51: 813-820.

Balbine M, Marcel E, Alexis K, Belkacem Z. 2015. Experimental Evaluation of the Thermal Performance of Dryer Airflow Configuration. International Journal of Energy Engineering. 5(4): 80-86.

Buscemi A, Panno D, Ciulla G, Beccali M, Lo Brano V. 2018. Concrete thermal energy storage for linear Fresnel collectors: Exploiting the South Meditteranean's solar potential for agrifood processes. Energy Conversion and Management. 166: 719-734. 
Bylung G. 2003. Dairy Processing Handbook. Tetra Pak Processing Systems AB.

Cengel YA, Boles, MA. 2015. Thermodynamics: An Engineering Approach. Eighth Edition, New York, USA.

Colak N, Hepbasli A. 2005. Use of renewable energy sources in food production systems. 3rd Renewable Energy Sources Symposium and Exhibition. Mersin, Turkey.

Dincer MZ, Aslan O. 2008. Sustainable development, Renewable Energy Sources and Hydrogen Energy: Turkey Assessment. Istanbul Chamber of Commerce Publication: Istanbul, Turkey.

Drescher S, Rao N, Kozak J, Okos M. 1997. A review of energy use in the food industry, American Council for an EnergyEfficient Economy - Summer Study on Energy Efficiency in Industry, USA.

European Comission. 2012. Analysis of options beyond 20\% GHG emission reductions: Member State results. Brussels, Belgium.

European Comission. 2015. JRC Science and Policy Report, Energy use in the EU food sector: State of play and opportunities for improvement. Online: http://publications. jrc.ec.europa.eu/repository/bitstream/JRC96121/ldna27247e nn.pdf

General Directorate of Energy Affairs. 2016. National Energy Balance Tables, Online: eigm.gov.tr.

Gupta A, Shukla SK, Srivastava AK. 2013. Analysis of solar drying unit with phase chance material storage system. International Journal of Agile Systems and Management. 6(2): 164-174.

International Renewable Energy Agency. 2014. Renewable Energy Options for The Industry Sector: Global and Regional Potential Until 2030. Online: https://irena.org//media/Files/IRENA/Agency/Articles/2016/Nov/IRENA_R E_Potential_for_Industry_BP_2015.pdf?la=en\&hash=1214 D8FDBD507297FC61073DACE78F8F31927663

Karthick SP, Helen Catherine RL. 2014. Modelling and Analysis of Solar Photovoltaic Thermal Collector. International Journal of Advanced Research in Electrical, Electronics and Instrumentation Engineering. 3(4): 8467-8474.
Kokey I. 2013. Determination of wind energy potential and the importance of exercise analysis in performance evaluation of wind power plants. International Energy and Environment Fair and Conference: Istanbul, Turkey.

Kosan M, Aktas M. 2018. Numerical analysis of a heat exchanger that stores thermal energy with phase change materials. Journal of Polytechnic. 21(2): 403-409.

Leon MA, Kumar S. 2015. Design and performance evaluation of a solar assited biomass drying system with a thermal storage. Drying Technology. 26: 936-947.

Mo JPT. 2016. Design of solar energy system in food manufacturing environment. Cogent Engineering. 3: 1-16.

Ozyurt O, Comakli O, Yilmaz M, Karsli S. 2004. Heat pump use in milk pasteurization: an energy analysis. International Journal of Energy Research. 28: 833-846.

Seck GS, Guerassimoff G, Maizi N. 2013. Heat recovery with heta pump in non-energy intensive industry: A detailed bottom-up model analysis in the French food \& drink industry. Applied Energy. 111: 489-504.

Tiwari S, Tiwari GN, Al-Helal IM. 2016. Performance analysis of photovoltaic-thermal (PVT) mixed mode greenhouse solar dryer. Solar Energy. 133: 421-428.

Viklund SB, Lindkvist E. 2015. Biogas production supported by excess heat - A systems analysis within the food industry. Energy Conversion and Management. 91; 249-258.

Wang L. 2013. Energy consumption and reduction strategies in food processing. Sustainable Food Processing. First Edition. 377-400.

Wang JF, Brown C, Cleland DJ. 2017. Heat pump heat recovery options for food industry dryers. International Journal of Refrigeration. 86: 48-55.

Wang LJ. 2008. Energy Efficiency and Management in Food Processing Facilities. Taylor and Francis: Boca Raton, USA.

Xu Y, Szmerekovsky J. 2017. System dynamic modeling of energy savings in the US food industry. Journal of Cleaner Production. 165: 13-26.

Yahya M. 2016. Design and performance evaluation of a solar assisted heat pump dryer integrated with biomass furnace for red chilli. International Journal of Photoenergy. 2016: 1-14. 